\title{
SCREENING OF SELECTED MALAYSIAN HERBS AS THE POTENTIAL BROAD SPECTRUM ANTIMICROBIAL AGENT AGAINST BACTERIAL DISEASES OF FISH
}

\author{
SYAHIDAH AHMAD ${ }^{1,2}$, HASSAN MOHD DAUD $^{2 *}$, YAYA RUKAYADI ${ }^{3}$, \\ YASSER MOHAMED ABDELHADI ${ }^{4}$, NOR ASMA HUSNA YUSOFF ${ }^{5}$ and \\ MOHD SALLEH KAMARUDIN ${ }^{1}$ \\ ${ }^{I}$ Department of Aquaculture, Faculty of Agriculture, Universiti Putra Malaysia, \\ 43400 UPM Serdang, Selangor, Malaysia \\ ${ }^{2}$ Aquatic Animal Health Unit, Faculty of Veterinary Medicine, Universiti Putra Malaysia, \\ 43400 UPM Serdang, Selangor, Malaysia \\ ${ }^{3}$ Laboratory of Natural Products, Institute of Bioscience, Universiti Putra Malaysia, \\ 43400 UPM Serdang, Selangor, Malaysia \\ ${ }^{4}$ Central Laboratory for Aquaculture Research, Abassa, Abu-Hammad, Sharkia, 44662, Egypt \\ ${ }^{5}$ Institute of Tropical Aquaculture and Fisheries, Universiti Malaysia Terengganu, \\ 21030 Kuala Nerus, Terengganu, Malaysia \\ *E-mail: hassanmd@upm.edu.my
}

Accepted 18 May 2021, Published online 5 June 2021

\begin{abstract}
The control of fish disease is mostly based on synthetic antimicrobial agents. Indiscriminate usage of antimicrobial agents has resulted in antibiotics resistance. Therefore, the present study aims to evaluate the potential antimicrobial properties of herbal plants as an alternative antimicrobial agent. The susceptibility of fish pathogens namely Bacillus sp., Enterococcus faecalis, Staphylococcus aureus, Streptococcus agalactiae, Aeromonas hydrophila, Escherichia coli, Klebsiella pneumoniae, Pseudomonas aeruginosa and Vibrio alginolyticus towards aqueous and methanolic extracts of Cosmos caudatus, Curcuma mangga, Justicia gendarussa, Piper betle and Zingiber zerumbet were assessed using the agar well diffusion, Minimum Inhibitory Concentration (MIC) and Minimum Bactericidal Concentration (MBC) assays. The methanolic extracts were found active against all tested bacteria, compared to aqueous extracts. The best antibacterial activity was demonstrated by methanolic extract of $P$. betle, followed by Z. zerumbet, C. caudatus, C. mangga and J. gendarussa, with the lowest MIC and $\mathrm{MBC}$ values of 0.39 and $1.56 \mathrm{mg} / \mathrm{mL}$, respectively. The methanolic extracts of $P$. betle and Z. zerumbet also had greater inhibitory effects than some of the commercial antibiotics, particularly tetracycline and erythromycin. Overall findings suggested that the methanolic extracts of $P$. betle and $Z$. zerumbet are potential to be developed as new antimicrobial agents to prevent fish bacterial diseases.
\end{abstract}

Key words: Antibacterial activity, fish pathogens, Malaysian herbs, methanolic extracts

\section{INTRODUCTION}

Bacterial diseases are recognised as one of the key threats to the success of fish production all over the world. It has been reported that diseases such as streptococcosis, vibriosis, pseudomonadiasis and motile aeromonads septicaemia have caused high rates of morbidity and mortality in both wild and cultured fishes (Pridgeon \& Klesius, 2012; Sudheesh

* To whom correspondence should be addressed. et al., 2012). As bacterial pathogens are ubiquitous in the natural habitats of fishes, they can easily infect farmed fishes from the wild counterparts (Murray, 2009). For example, the cases of streptococcosis infection in Malaysia which is caused by Streptococcus agalactiae has been reported to result in 50-100\% of mortalities among cage-cultured tilapia, and have caused major losses to the farmers (Sulaiman, 2019).

The common strategy of controlling the outbreak of diseases with antimicrobial agents will partly 
overcome these problems (Maheswaran et al., 2013). However, the indiscriminate use of antibiotics has led to a surge of incidences whereby pathogenic bacteria are becoming resistant to common antibiotics (Davies \& Davies, 2010). One of the ways to prevent antibiotic resistance is through the development of new antibacterial substances which are not based on the existing synthetic antimicrobial agents.

To date, a lot of effort has been put into discovering new antimicrobials from numerous sources such as microorganisms, animals and plants. Of these approaches, plants seem to be the most promising alternative as they contain a wide variety of secondary metabolites (Kumar \& Roy, 2017). Besides, they are preferred due to their low toxicity, minimal side-effects, eco-friendly, and available at a cheaper cost (Raman, 2017).

As one of the top 12 countries with the richest biodiversities in the world, Malaysia owns about 12,500 plant species where traditional systems of medicinal therapy are commonly practised (Latif, 2007). Several native herbs have been traditionally used to cure different kinds of human ailments such as diarrhoea, cough, cholera, fever, bronchitis, gastrointestinal tract diseases, irritations, skin infections and inflammations in folkloric medicine preparations (Hassan, 2006; Aziz \& Tey, 2009; Abd Aziz et al., 2011; Yob et al., 2011; Subramanian et al., 2012). Nevertheless, only a few of them have been fully investigated for their medicinal potential while the rest remained unexplored. Hence, the systemic screening of the herbs may generate new drug discovery.

The present study was carried out to assess the antimicrobial activities of five Malaysian herbs, namely Cosmos caudatus, Curcuma mangga, Justicia gendarussa, Piper betle and Zingiber zerumbet used in traditional remedies against the fish bacterial pathogens. The claims of effective therapy for numerous treatments of diseases, including infectious diseases by traditional local herbalists have prompted our interest to scientifically investigate these herbs. The extracts of the herbs are hypothesised to have active antimicrobial properties that can be the potential sources of antimicrobials in aquaculture to combat the increasing number of bacterial strains that are resistant to commonly-used antibiotics.

\section{MATERIALS AND METHODS}

\section{Herbs collection and extraction}

Five herbal species used in this study (Table 1) were collected from Herbal Garden, University Agricultural Park of Universiti Putra Malaysia (UPM). They were selected as they have been traditionally used in the treatment of various diseases, primarily associated with microorganisms. Botanical identification of the plants was done by a botanist from the Plant Genetics Unit, Institute of Bioscience (IBS), UPM and the voucher specimens were deposited at the Herbarium of IBS with voucher numbers of SK2668/15 (C. caudatus), SK3368/18 (C. mangga), SK2834/15 (J. gendarussa), SK3361/18 (P. betle) and SK3369/18 (Z. zerumbet), respectively.

Harvested plants were washed with running tap water to remove the dirt and other debris. The plant parts were separated and cut into small pieces and later dried in a laboratory oven (Memmert UF30 $0^{\mathrm{TM}}$, Schwabach, Germany) at $40^{\circ} \mathrm{C}$ for several days. The plants were ground into a fine powder using a laboratory grinder (Waring ${ }^{\circledR}$ Commercial, USA). The herb powders were extracted using two types of solvents, namely methanol and deionised distilled water at ratios of 1:3 and 1:10 (w/v), respectively. These were prepared in $2 \mathrm{~L}$ conical flasks and the flask mouths were tightly covered with aluminium foil to avoid organic solvent evaporation into the air. The concoctions were allowed to stand for a week at room temperature. Each extract was then filtered

Table 1. List of selected Malaysian herbs used in the study and related traditional treatments

\begin{tabular}{|c|c|c|c|}
\hline Scientific name & Local name & Part of the plant used & Traditional treatments \\
\hline Cosmos caudatus & Ulam Raja & Leaf & $\begin{array}{l}\text { Infectious diseases, skin diseases, body heat and promote } \\
\text { fresh breath (Hassan, 2006; Bodeker et al., 2009). }\end{array}$ \\
\hline Curcuma mangga & Temumangga & Rhizome & $\begin{array}{l}\text { Digestive problems, bloating, diabetic wounds, sinusitis, } \\
\text { inflammation and ulcers (Sasikumar, 2005). }\end{array}$ \\
\hline Justicia gendarussa & Gandarusa & Leaf & $\begin{array}{l}\text { Digestive problems, eczema, eye diseases, bronchitis, } \\
\text { rheumatism, fever and headache (Subramaniam et al., } \\
\text { 2012). }\end{array}$ \\
\hline Piper betle & Sireh & Leaf & $\begin{array}{l}\text { Halitosis, itchiness, conjunctival infections, abscesses, } \\
\text { leucorrhoea, mastitis, rheumatism and headache } \\
\text { (Pradhan et al., 2013). }\end{array}$ \\
\hline Zingiber zerumbet & Lempoyang & Rhizome & $\begin{array}{l}\text { Inflammation, indigestion, diarrhoea, stomach ache, } \\
\text { bronchitis, fever, worm infestation, sores and skin } \\
\text { diseases (Yob et al., 2011). }\end{array}$ \\
\hline
\end{tabular}


using a Whatman ${ }^{\circledR}$ No. 1 membrane filter paper and concentrated under vacuum using a rotary evaporator (Buchi ${ }^{\circledR} \mathrm{R}-210$, Switzerland) at $50^{\circ} \mathrm{C}$ for methanol and $70^{\circ} \mathrm{C}$ for deionised distilled water. The crude extracts were placed in amber bottles and stored in a freezer at $-20^{\circ} \mathrm{C}$ until further use.

\section{Bacterial species}

Nine known fish pathogens consisted of four Gram-positive (Bacillus sp., Enterococcus faecalis, Staphylococcus aureus and Streptococcus agalactiae) and five Gram-negative bacteria (Aeromonas hydrophila, Escherichia coli, Klebsiella pneumoniae, Pseudomonas aeruginosa and Vibrio alginolyticus) were used in this study. All the bacterial species were isolated from diseased fish and the stock cultures were obtained from the Microbiology Laboratory of the Aquatic Animal Health Unit (AAHU) and Bacteriology Laboratory, Faculty of Veterinary Medicine, UPM.

\section{Antibacterial screening}

The antibacterial activities of the methanolic and aqueous extracts of the herbs were tested by agar well diffusion according to Perez et al. (1990) with slight modifications. The herbal extracts were dissolved in their respective solvents to give final concentrations of 10, 25, 50 and $100 \mathrm{mg} / \mathrm{mL}$. Mueller Hinton Agar (MHA; Merck®, Germany), the medium for the tested bacteria was prepared in disposable plates and all the plates were labelled accordingly. Bacterial cell suspensions were prepared by growing the isolates in Mueller Hinton Broth (MHB; Merck ${ }^{\circledR}$, Germany) at $35^{\circ} \mathrm{C}$ for overnight. After confirmation with a spectrophotometer at $\mathrm{OD}_{600}, 100 \mu \mathrm{L}$ of inocula containing $10^{8} \mathrm{cfu} / \mathrm{mL}$ of bacterial suspension were spread evenly onto the MHA surface using a sterile L-shaped glass rod. The inoculated plates were allowed to dry and wells (6 $\mathrm{mm}$ diameter) were punched out from the agar using a sterilised wellpuncher. Subsequently, $50 \mu \mathrm{L}$ of each extract was introduced into respective wells on the agar plate. Another well was inserted either with methanol $(\mathrm{MeOH})$ or deionized distilled water $\left(\mathrm{ddH}_{2} \mathrm{O}\right)$ to serve as a negative control, while tetracycline $(30 \mu \mathrm{g})$ was used as a positive control. All the plates were incubated at $35^{\circ} \mathrm{C}$ for $24 \mathrm{hr}$ and any clear zone encircling the wells were measured in millimetres $(\mathrm{mm})$. The strengths of activity were classified as strong for IZ (inhibition zone) diameters of $\geq 16 \mathrm{~mm}$, intermediate for IZ diameters ranging from 11-15 mm and weak for IZ diameters ranging from 7-10 $\mathrm{mm}$.

\section{Determination of minimum inhibitory concentration (MIC) and minimum bactericidal concentration (MBC) \\ The MIC of herbal extracts against pathogenic} bacteria was performed using the standard broth microdilution method with an inoculum of $10^{6} \mathrm{cfu} /$ $\mathrm{mL}$, as described in the guidelines of the Clinical Laboratory Standard Institute M7-A6 M7-A6 (CLSI, 2003). For each bacterial species, a $100 \mu \mathrm{L}$ inoculum was placed into each well of column 12 to column 3 in the 96-well round-bottomed plates. This was followed by the addition of $100 \mu \mathrm{L}$ of each herbal extract $(100 \mathrm{mg} / \mathrm{mL})$. Then, two-fold serial dilutions were made to achieve the concentrations of 50,25 , $12.50,6.25,3.13,1.56,0.78,0.39,0.195$ and $0.098 \mathrm{mg} /$ $\mathrm{mL}$. The wells that were filled with respective bacteria diluent only (Column 2) were considered as the positive controls, while the wells that were filled with MHB (Column 1) were considered as the negative controls. After $24 \mathrm{hr}$ of incubation at $35^{\circ} \mathrm{C}$, the MIC values were visually evaluated by comparing the concentrations of the herbal extracts, whereby the turbidities of the wells had to be less than those of the positive control wells.

The MBC was determined by pipetting $10 \mu \mathrm{L}$ of the mixtures from all 96-wells plates onto MHA plates. The plates were then incubated at $35^{\circ} \mathrm{C}$ for $24 \mathrm{hr}$, or until growth could be observed in the positive controls. MBC was the value at which there was no microbial growth (Zainin et al., 2013).

\section{Antibiotic susceptibility test}

An antibiotic susceptibility test was done to measure the ability of common antibiotics to inhibit the growth of the fish pathogens. The test was determined by the disc diffusion method, according to the protocol as stated by Bauer et al. (1966). In brief, $100 \mu \mathrm{L}$ overnight cultures $\left(10^{8} \mathrm{cfu} / \mathrm{mL}\right)$ were spotted and spread over the MHA media. Standard antibiotic discs of enrofloxacin (ENR, $5 \mu \mathrm{g}$ ), erythromycin (E, $15 \mu \mathrm{g})$, oxytetracycline (OTC, $30 \mu \mathrm{g}$ ) and tetracycline (TET, $30 \mu \mathrm{g}$ ) (Oxoid Ltd, UK) were placed on the surfaces of the inoculated agar plates using sterile forceps. These were later incubated at $35^{\circ} \mathrm{C}$ for $24 \mathrm{hr}$. After the incubation period, the diameter of the inhibition zones was measured in millimeters ( $\mathrm{mm}$ ) and interpreted as sensitive (S), intermediate (I), or resistant (R) by referring to the approved standard as per the CLSI standard M2-A9 (CLSI, 2006). All experiments were repeated three times, with triplicate.

\section{RESULTS}

\section{Antibacterial activity}

There was a large variation in the inhibitory effects of the herbal extracts against the bacteria as shown in Tables 2 and 3. The methanolic extract of herbs as a whole demonstrated broad-spectrum antibacterial activities by inhibiting the growths of all tested bacteria (Table 2). They were found to express active inhibitions at concentrations of 50 and 


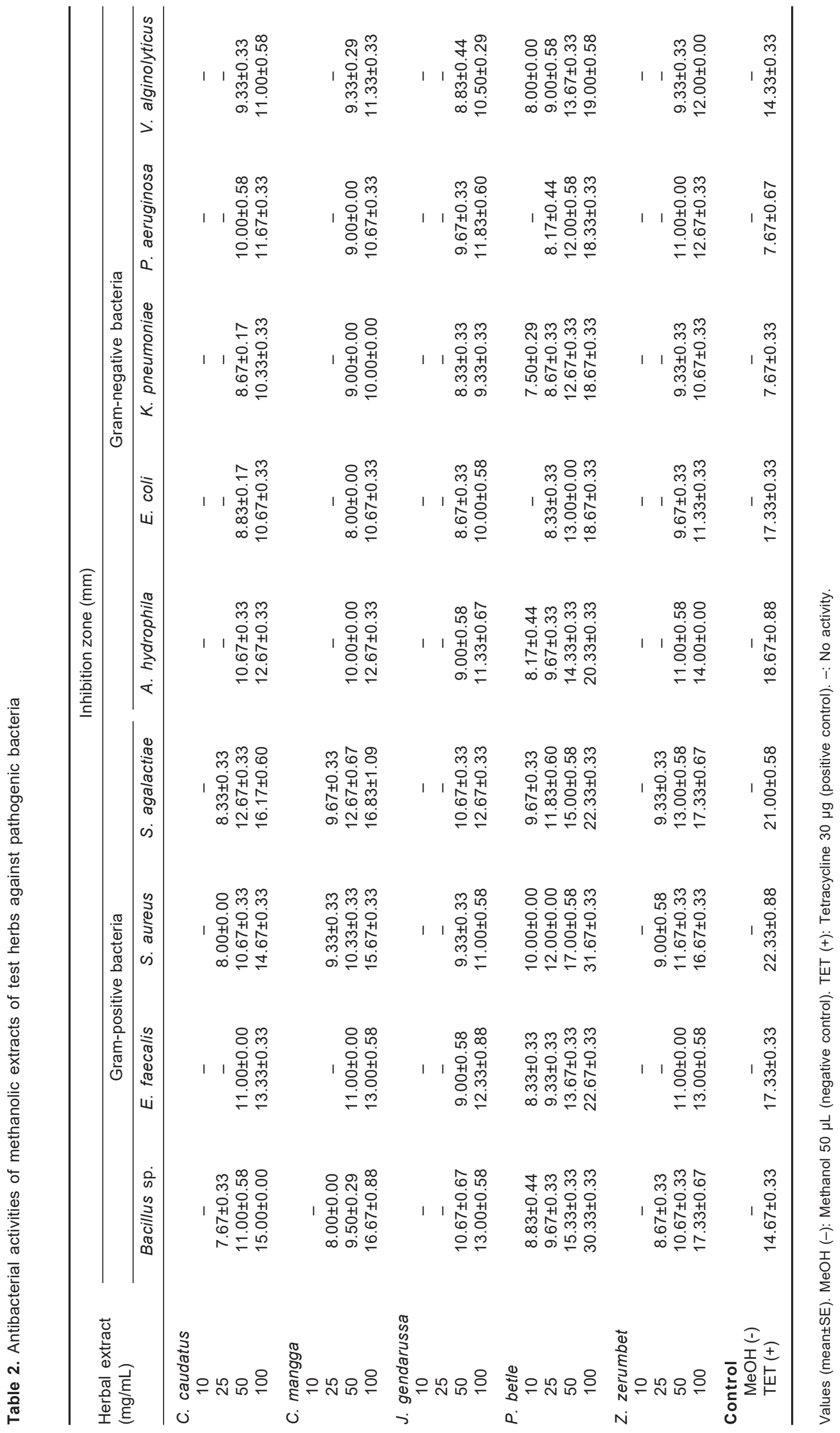




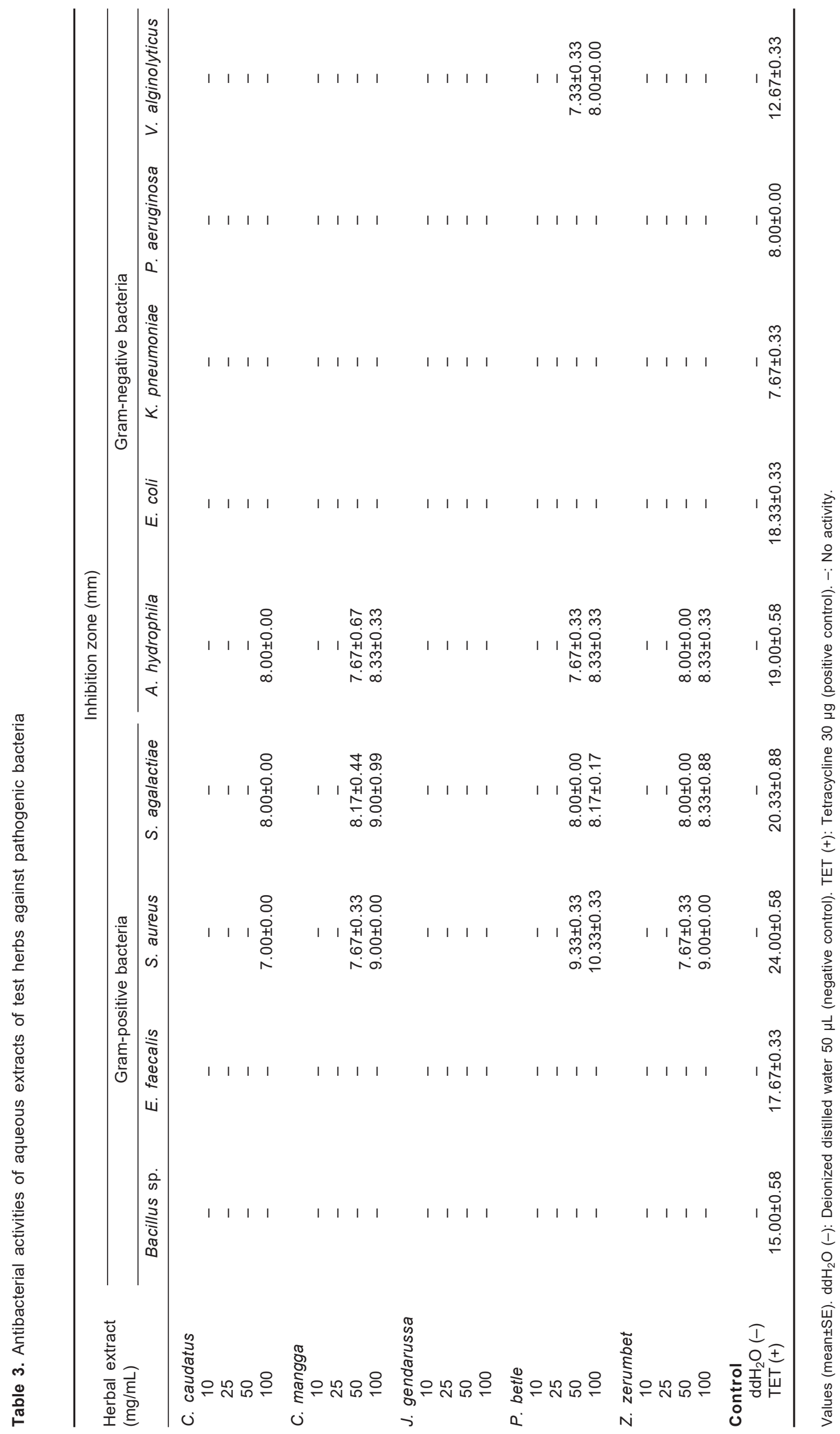


$100 \mathrm{mg} / \mathrm{mL}$, with intermediate-to-strong antibacterial activities (Figures 1a, 1b and 2a, 2b). Among the investigated herbs, methanolic extracts of $P$. betle showed the highest inhibition as compared to $Z$. zerumbet, C. caudatus, C. mangga and J. gendarussa. The strongest antibacterial activities were exhibited by the $100 \mathrm{mg} / \mathrm{mL}$ methanolic extract of $P$. betle, with an inhibition zone of $31.67 \pm 0.33 \mathrm{~mm}$ against $S$. aureus.

On the other hand, most of the bacteria were not affected by the aqueous extracts (Table 3). Only slight inhibitions (weak activities) were detected in C. caudatus, C. mangga, $P$. betle and Z. zerumbet against $S$. aureus, $S$. agalactiae, A. hydrophila and $V$. alginolyticus at 50 and/or $100 \mathrm{mg} / \mathrm{mL}$. The maximum inhibition for aqueous extracts was possessed by $100 \mathrm{mg} / \mathrm{mL} P$. betle, with $10.33 \pm 0.33$ mm of inhibition zone against $S$. aureus. Meanwhile, no inhibition zone was observed for the aqueous extract of $J$. gendarussa at all concentrations towards the tested bacteria.

The herbs of both extraction solvents were noticed to have a greater inhibitory action on Grampositive rather than Gram-negative bacteria. In this assay, $S$. agalactiae and $S$. aureus were the most sensitive bacteria to the methanolic and some of the aqueous extracts tested, whereas $K$. pneumoniae was found to be insensitive.

\section{Minimum inhibitory concentration (MIC) and minimum bactericidal concentration (MBC)}

Since the aqueous extracts demonstrated inactive antibacterial activities, only methanolic extracts were assessed for MIC and MBC. According
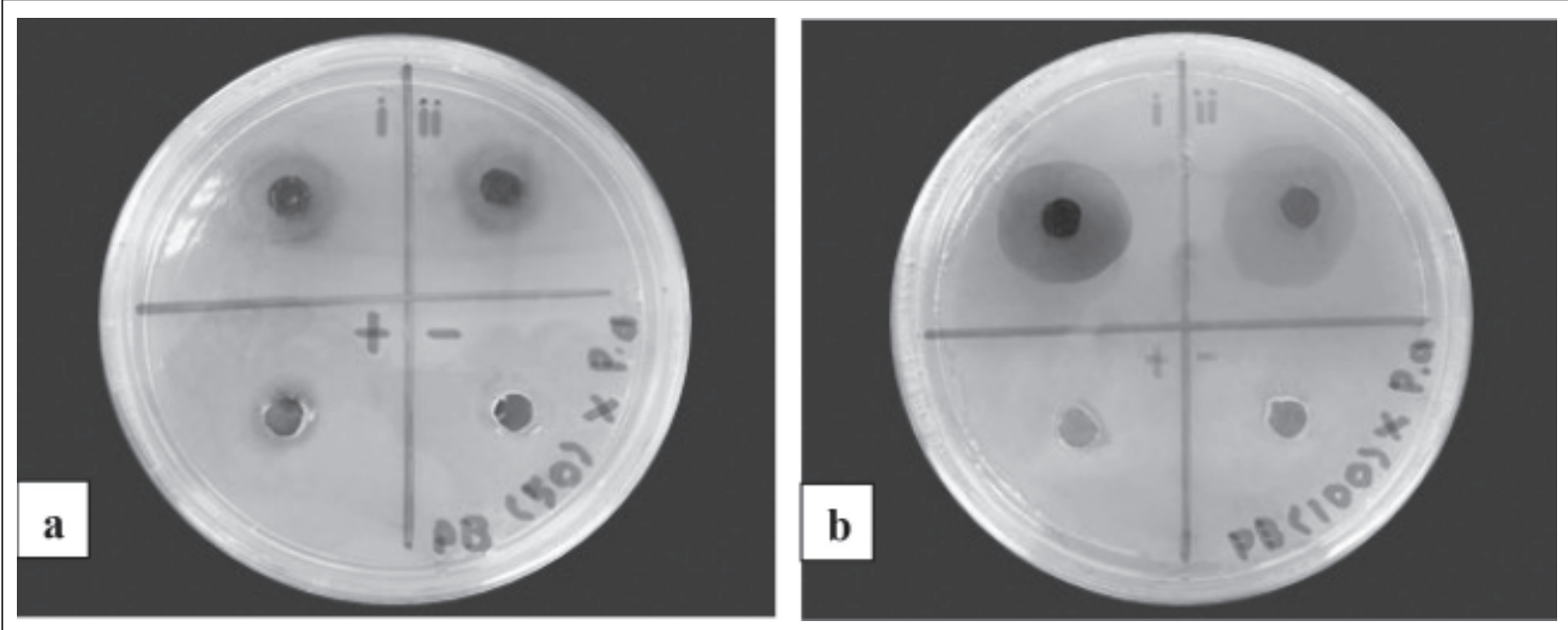

Fig. 1. Inhibition zones of $P$. betle against $P$. aeruginosa at (a) 50 and (b) $100 \mathrm{mg} / \mathrm{mL}$. i \& ii: the replicates of $P$. betle methanolic extract. +: tetracycline as the positive control. -: methanol as the negative control.
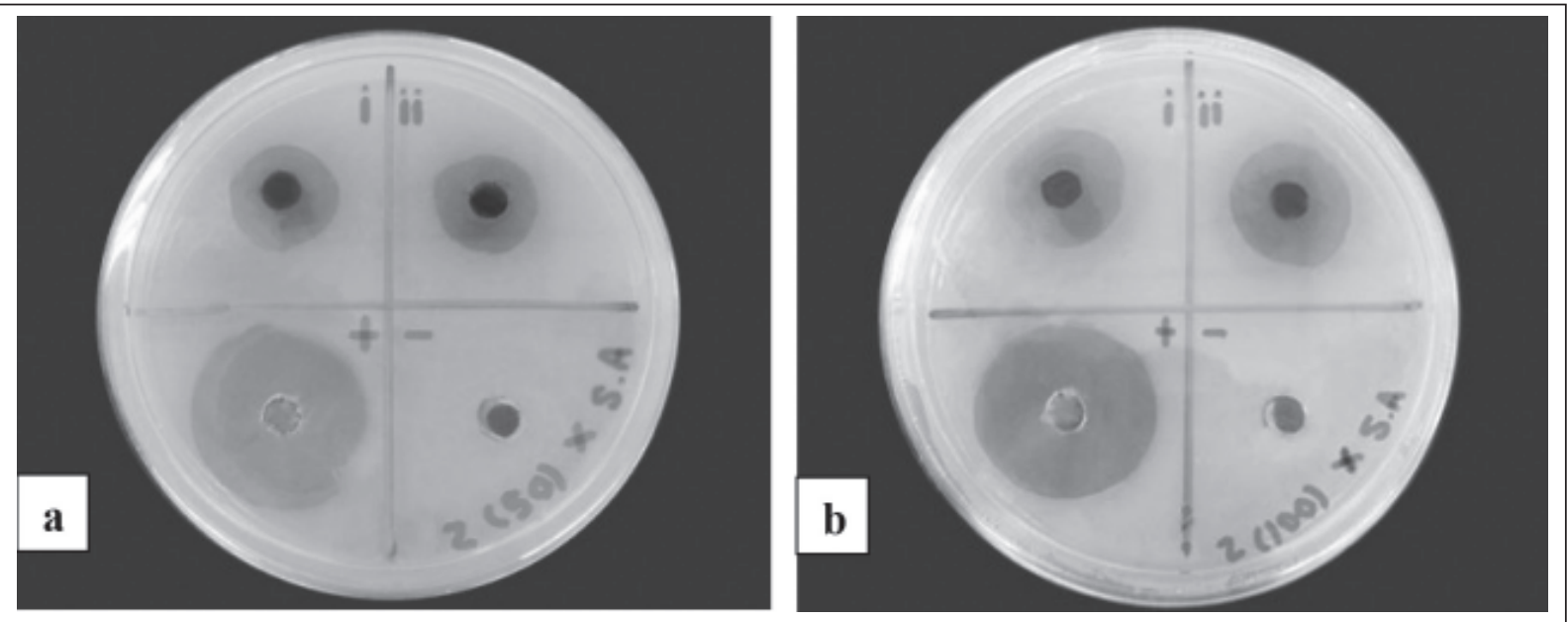

Fig. 2. Inhibition zones of $Z$. zerumbet against $S$. agalactiae at (a) 50 and (b) $100 \mathrm{mg} / \mathrm{mL}$. i \& ii: the replicates of $Z$. zerumbet methanolic extract. +: tetracycline as the positive control. - : methanol as the negative control. 
to the results (Table 4), the lowest MIC and MBC values for the methanolic extracts were 0.39 and 1.56 $\mathrm{mg} / \mathrm{mL}$, respectively, exhibited by $P$. betle against $S$. aureus. Meanwhile, other herbs showed variable MIC and MBC values towards the tested bacteria. All methanolic extracts showed the highest MIC and $\mathrm{MBC}$ values at concentrations of 12.50 and $25.00 \mathrm{mg} /$ $\mathrm{mL}$ against $K$. pneumoniae, except $P$. betle. The results also indicated that the methanolic extracts had low MIC and MBC values against Gram-positive bacteria as compared to Gram-negative bacteria. From the assays, the best bacteriostatic and bactericidal activities were demonstrated by $P$. betle, followed by $Z$. zerumbet, C. caudatus, C. mangga and $J$. gendarussa.

\section{Antibiotic susceptibility}

Results of the antibiotic susceptibility test (Table 5) indicated that all tested bacteria were inhibited by enrofloxacin, oxytetracycline, and tetracycline, but not by erythromycin. Most of the bacteria were found sensitive towards enrofloxacin and oxytetracycline, with the largest inhibition zones of $33.00 \pm 1.15$ and $27.00 \pm 0.58 \mathrm{~mm}$, respectively against E. faecalis. Tetracycline showed varying inhibitory effects ranging from $8.67 \pm 0.33$ to $22.67 \pm 0.33 \mathrm{~mm}$ which is considered as an intermediate resistance. On the other hand, erythromycin showed the weakest inhibition, whereby the bacteria were mostly found to be resistant towards it.

Table 6 shows the susceptibility profiles and the percentages of the tested bacterial species towards standard antibiotics. The results revealed $77.78 \%$ of the bacteria were sensitive to enrofloxacin and oxytetracycline, whereas $44.44 \%$ and $77.78 \%$ were resistant to tetracycline and erythromycin. Overall, Bacillus sp., $K$. pneumoniae, $P$. aeruginosa and $V$. alginolyticus had greater resistance against the antibiotics compared to E. faecalis, S. aureus, $S$. agalactiae, A. hydrophila and E. coli.

Table 4. MIC and MBC values of methanolic extracts of test herbs against pathogenic bacteria

\begin{tabular}{|c|c|c|c|c|c|c|c|c|c|c|}
\hline \multirow{2}{*}{ Bacterial species } & \multicolumn{2}{|c|}{ C. caudatus } & \multicolumn{2}{|c|}{ C. mangga } & \multicolumn{2}{|c|}{ J. gendarussa } & \multicolumn{2}{|c|}{ P. betle } & \multicolumn{2}{|c|}{ Z. zerumbet } \\
\hline & MIC & $\mathrm{MBC}$ & MIC & $\mathrm{MBC}$ & MIC & MBC & MIC & $\mathrm{MBC}$ & MIC & MBC \\
\hline \multicolumn{11}{|l|}{ Gram-positive } \\
\hline Bacillus sp. & 6.25 & 12.50 & 3.13 & 12.50 & 6.25 & 12.50 & 0.78 & 1.56 & 3.13 & 12.50 \\
\hline E. faecalis & 3.13 & 12.50 & 6.25 & 25.00 & 6.25 & 12.50 & 0.78 & 1.56 & 6.25 & 25.00 \\
\hline S. aureus & 6.25 & 12.50 & 6.25 & 12.50 & 6.25 & 25.00 & 0.39 & 1.56 & 3.13 & 12.50 \\
\hline S. agalactiae & 3.13 & 12.50 & 3.13 & 6.25 & 6.25 & 25.00 & 0.78 & 3.13 & 3.13 & 6.25 \\
\hline \multicolumn{11}{|l|}{ Gram-negative } \\
\hline A. hydrophila & 3.13 & 12.50 & 6.25 & 12.50 & 6.25 & 12.50 & 0.78 & 3.13 & 3.13 & 6.25 \\
\hline E. coli & 12.50 & 25.00 & 12.50 & 25.00 & 12.50 & 25.00 & 1.56 & 3.13 & 6.25 & 25.00 \\
\hline K. pneumoniae & 12.50 & 25.00 & 12.50 & 25.00 & 12.50 & 25.00 & 1.56 & 3.13 & 12.50 & 25.00 \\
\hline$P$. aeruginosa & 12.50 & 25.00 & 12.50 & 25.00 & 6.25 & 25.00 & 1.56 & 3.13 & 6.25 & 12.50 \\
\hline V. alginolyticus & 6.25 & 25.00 & 6.25 & 25.00 & 6.25 & 12.50 & 0.78 & 3.13 & 6.25 & 25.00 \\
\hline
\end{tabular}

MIC minimum inhibition concentration; $M B C$ minimum bactericidal concentration.

Table 5. Inhibition zones of standard antibiotics against pathogenic bacteria

\begin{tabular}{lccc}
\hline & \multicolumn{3}{c}{ Inhibition zone $(\mathrm{mm})$} \\
\cline { 2 - 4 } Bacterial species & $\begin{array}{c}\text { Enrofloxacin } \\
(5 \mu \mathrm{g})\end{array}$ & $\begin{array}{c}\text { Erythromycin } \\
(15 \mu \mathrm{g})\end{array}$ & $\begin{array}{c}\text { Oxytetracycline } \\
(30 \mu \mathrm{g})\end{array}$ \\
\hline Gram-positive & & & \\
Bacillus sp. & $30.00 \pm 0.58$ & $12.33 \pm 0.33$ & $19.33 \pm 0.33$ \\
E. faecalis & $33.00 \pm 1.15$ & $10.67 \pm 0.33$ & $27.00 \pm 0.58$ \\
S. aureus & $28.67 \pm 0.33$ & $21.33 \pm 0.67$ & $24.67 \pm 0.33$ \\
S. agalactiae & $26.00 \pm 0.58$ & $10.67 \pm 0.33$ & $23.33 \pm 0.33$ \\
Gram-negative & & & $12.67 \pm 0.33$ \\
A. hydrophila & $29.67 \pm 0.33$ & $17.33 \pm 0.33$ & $22.67 \pm 0.33$ \\
E. coli & $24.33 \pm 0.33$ & $7.67 \pm 0.33$ & $19.33 \pm 0.33$ \\
K. pneumoniae & $13.00 \pm 0.58$ & - & $11.83 \pm 0.17$ \\
$P$. aeruginosa & $19.33 \pm 0.33$ & - & $12.33 \pm 0.33$ \\
V. alginolyticus & $21.33 \pm 0.67$ & $11.00 \pm 0.58$ & $19.00 \pm 0.58$ \\
\hline
\end{tabular}

Values (mean \pm SE). -: No activity. 
Table 6. Percentages of antibiotic sensitivities of pathogenic bacteria

\begin{tabular}{|c|c|c|c|c|c|c|c|c|c|c|}
\hline \multirow[b]{3}{*}{ 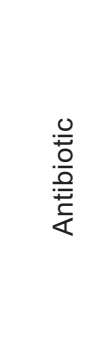 } & \multicolumn{10}{|c|}{ Category of sensitivity } \\
\hline & \multicolumn{4}{|c|}{ Gram-positive bacteria } & \multicolumn{6}{|c|}{ Gram-negative bacteria } \\
\hline & $\begin{array}{l}\text { o } \\
0 \\
\text { s } \\
\text { 어 } \\
\mathbb{D}\end{array}$ & 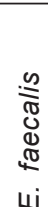 & 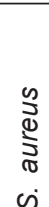 & 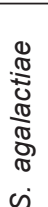 & $\begin{array}{l}\frac{\pi}{2} \\
\frac{0}{2} \\
\frac{0}{2} \\
0 \\
0\end{array}$ & ¿े & 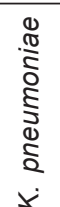 & 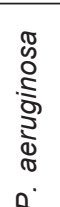 & 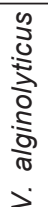 & の \\
\hline ENR & $\mathrm{s}$ & $\mathrm{s}$ & S & $\mathrm{s}$ & S & s & $\mathrm{R}$ & 1 & $\mathrm{~s}$ & 77.78 \\
\hline$E$ & $\mathrm{R}$ & $\mathrm{R}$ & I & $R$ & I & $\mathrm{R}$ & $\mathrm{R}$ & $\mathrm{R}$ & $\mathrm{R}$ & 0 \\
\hline отс & $\mathrm{S}$ & $\mathrm{S}$ & $S$ & $\mathrm{~S}$ & $S$ & $S$ & $\mathrm{R}$ & $\mathrm{R}$ & $S$ & 77.78 \\
\hline TET & $\mathrm{R}$ & I & $S$ & I & I & I & $\mathrm{R}$ & $\mathrm{R}$ & $\mathrm{R}$ & 11.11 \\
\hline
\end{tabular}

ENR Enrofloxacin; E Erythromycin; OTC Oxytetracycline; TET Tetracycline.

$R$ resistant; I intermediate; $S$ sensitive.

\section{DISCUSSION}

The findings of the current study provided scientific evidence on the traditional use of selected Malaysian herbs, C. caudatus, C. mangga, J. gendarussa, P. betle and $Z$. zerumbet as therapeutic agents since they showed marked inhibitory effects against pathogenic bacteria. Methanolic extracts, however, expressed active inhibition compared to aqueous extracts which were inactive or slightly inhibitory against the bacteria. The activity difference between samples might probably be due to the differences in polarity that resulted in the variations in extracted active compounds. The capability of methanol to dissolve saturated organic and active antimicrobial compounds could be described by the organic nature of methanol, which was less polar than water (Cowan, 1999). On the other hand, water was very polar and only miscible in itself (Thabile, 2008). Therefore, the active lipophilic constituents in the herbs were not extracted by water.

The success in the extraction of compounds from herbal plants largely depends upon the type of solvent used during the extraction process (Nasir et al., 2015). Although aqueous extraction might be popular, the results of the current study have indicated that it was not necessarily the most effective solvent. Many earlier studies have also reported that the methanol extracts had superior and broader antimicrobial activities in contrast to other diluents such as water and hexane (Karaman et al., 2003; Mothana \& Lindequist, 2005; Parekh et al., 2005; Abdallah et al., 2009; Al-Daihan et al., 2013; Naz \& Bano, 2013; Zubair et al., 2017). According to Samir et al. (2017), the efficiency of methanol is correlated to the intermediate polarity that allows it to solvate low molecular weight organic compounds which possess protonatable functional groups such as $\mathrm{COOH}$ and $\mathrm{OH}$. By the present findings, it could be deduced that methanol was a better solvent that could consistently extract antimicrobial substances from plants. Apart from that, other factors such as the quantity of extract used, plant extraction procedure, variation of genes, age of the plant and the environment might have also influenced the efficacy of the herbal extracts in determining the antimicrobial effects (Thakera, 2004).

The antibacterial activities in the present study were found to be dose-dependent, as it was observed that the inhibitory effects of the extracts proportionately increased with an increase in concentration. Besides, it seemed that the antibacterial assays of the tested herbal extracts were suitable to be of high concentrations between 50 to $100 \mathrm{mg} / \mathrm{mL}$, with the greatest inhibitory actions demonstrated by the $P$. betle methanolic extract. These results reflected the presence of potent antibacterial compounds in the $P$. betle extract as compared to other herbal extracts at the tested concentrations. The inhibitory effects of the herbal extracts of a certain concentration on a particular species could be linked to the presence of one or more bioactive compounds. However, the exact mode of action for this was still not well understood. Several studies have reported that the antibacterial activities of $P$. betle extract could be attributed to its phenolic compounds, with hydroxychavicol and eugenol as the main constituents (Nalina \& Rahim, 2007; Annegowda et al., 2013; Syahidah et al., 2017).

Meanwhile, the weakest inhibitory effect was shown by $J$. gendarussa, although Subramanian et al. (2012) have stated that $J$. gendarussa contained active ingredients such as tannins, glycosides, terpenoids, as well as flavonoids which could have accounted for its antimicrobial activity. The aqueous extract of this herb did not exhibit any antibacterial activity, whereas the methanolic extract possessed greater antibacterial activities at increasing 
concentration. Hence, the results of this study correlated with the fact that the compounds responsible for antibacterial activities were of different concentrations in each extract. Some were unable to exhibit their antibacterial properties at low concentration (Rasdi et al., 2010).

Different bacterial species also exhibited variable sensitivities towards the tested herbal extracts. In this study, $S$. agalactiae had the highest sensitivity followed by $S$. aureus, whereas $K$. pneumoniae was insensitive. The results were consistent with the findings of Joshi et al. (2011), Mehmood et al. (2012) and Shaikh et al. (2017) that Gram-positive bacteria tend to be more susceptible to the inhibitory effects of plant extracts than Gram-negative bacteria. This was possibly due to the modes of action and the common differences in the microbial cell walls between the species. The sensitivity of Gram-positive bacteria towards antimicrobial substances was associated with the single-layer and lack of natural sieve effect against large molecules. Conversely, Gram-negative bacteria have a multi-layered and complex structure of the cell wall (Pradhan et al., 2013).

It is important to note that plant extracts possess higher antibacterial potential when they exhibit lower MIC and MBC values (Chiao-Wei et al., 2011). Overall, the lowest MIC and MBC values of the tested extracts were 0.39 and $1.56 \mathrm{mg} / \mathrm{mL}$, while the highest values were 12.50 and $25.00 \mathrm{mg} / \mathrm{mL}$, respectively. Herbal extracts showed variable efficacy against the tested bacteria in this study. Nevertheless, higher MIC and MBC values of the tested extracts attributed to the activities of $E$. coli, $K$. pneumoniae and $P$. aeruginosa which were less sensitive as compared to other bacteria. Of the five herbs tested, $P$. betle demonstrated to be the most effective extract and showed bacteriostatic and bactericidal activities against the tested bacteria with MIC's ranged from 0.39 to $1.56 \mathrm{mg} / \mathrm{mL}$ and $\mathrm{MBC}$ of 1.56 to $3.13 \mathrm{mg} / \mathrm{mL}$. To the best of our knowledge, the antibacterial properties of the studied herbs against fish pathogenic bacteria have been reported for the first time. Therefore, no evaluations with the same herbs/bacterial species could be made. However, the results were comparable to those of Najiah et al. (2011). They have used the methanolic extracts of different edible herbs, i.e. clove, curry leaf and Vietnamese coriander and found the lowest MIC value against $S$. agalactiae to be $0.39 \mathrm{mg} / \mathrm{mL}$.

Most of the tested bacteria were shown to be resistant to certain antibiotics, particularly erythromycin and tetracycline. The current findings have indicated the linkage of the resistance mechanisms to the potential causes of aquaculture antibiotic treatment failures. The bacterial pathogens demonstrated resistance, possibly due to manipulations of the transportable elements, conjugations between organisms, transformations and mutations (Rani \& Khullar, 2004). Some bacterial species might survive unfavourable conditions or environmental changes after undergoing mutations that improved their fitness in the new surroundings (Romero et al., 2012). Hence, the effectiveness of the antibiotics in treating fish diseases was compromised.

Interestingly, the results of the current study indicated that the zones of inhibition of $P$. betle, $Z$. zerumbet, C. caudatus, C. mangga and $J$. gendarussa methanolic extracts against Bacillus sp., S. agalactiae, E. faecalis, E. coli, K. pneumoniae and $P$. aeruginosa were greater than those of erythromycin. This suggested that the bacterial species were more sensitive to the herbal extracts as compared to this antibiotic. Meanwhile, $P$. betle and Z. zerumbet methanolic extracts at $100 \mathrm{mg} / \mathrm{mL}$ showed the inhibition zones almost similar to oxytetracycline and tetracycline; the broad-spectrum antibiotics that are commonly used for the treatment of infectious diseases (FAO, 2005). The best performance for both antibiotics and herbal extracts, on the whole, could be presented in the following descending order of effectiveness: enrofloxacin, $P$. betle, oxytetracycline, $Z$. zerumbet, tetracycline, $C$. caudatus, and erythromycin. These herbs had a high potential to be potent antimicrobial agents since they were as effective and that the effects were comparable or even better than those of commercial antibiotics, considering that the herbs were tested in a crude form rather than an active substance as employed by antibiotics. Moreover, the prevalence of antibiotic resistance among fish pathogenic microorganisms could be controlled because, unlike antibiotics, bacteria were unable to easily develop resistance towards multiple and chemically complex phytochemicals in herbal extracts (Gupta \& Birdi, 2017).

\section{CONCLUSION}

The present study indicates that the methanolic extracts of selected Malaysian herbs had broadspectrum antibacterial activities. The herbs especially $P$. betle and $Z$. zerumbet methanolic extracts also showed greater inhibitory effects than some of the commercial antibiotics. It could be inferred that the herbs have great potential to become natural antimicrobial agents for the treatment of fish bacterial diseases. Hence, with the incidence of diseases and emergence of antibiotic resistance, these antimicrobials could be an alternative to the synthetic antibiotics that may appropriately apply via bath treatment, parenteral administration or oral application in fish feed. 


\section{ACKNOWLEDGEMENTS}

High appreciation goes to Universiti Putra Malaysia for financial support through Research University Grant Scheme (RUGS 9325300), Taman Herba, University Agriculture Park for supplying the plant materials, and Bacteriology Lab, Faculty of Veterinary Medicine for providing the bacterial stocks.

\section{REFERENCES}

Abd Aziz, S.M., Low, C.N., Chai, L.C., Abd Razak, S.S.N., Selamat, J., Son, R. \& Khatib, A. 2011. Screening of selected Malaysian plants against several food borne pathogen bacteria. International Food Research Journal, 18(3): 11951201.

Abdallah, E.M., Khalid, A.S. \& Ibrahim, N. 2009. Antibacterial activity of oleo-gum resins of Commiphora molmol and Boswellia papyrifera against methicillin resistant Staphylococcus aureus (MRSA). Scientific Research and Essay, 4(4): 351-356.

Al-Daihan, S., Al-Faham, M., Al-shawi, N., Almayman, R., Brnawi, A., Zargar, S. \& Bhat, R.S. 2013. Antibacterial activity and phytochemical screening of some medicinal plants commonly used in Saudi Arabia against selected pathogenic microorganisms. Journal of King Saud University - Science, 25(2): 115-120.

Annegowda, H.V., Tan, P.Y., Mordi, M.N., Ramanathan, S., Hamdan, M.R., Sulaiman, M.H. \& Mansor, S.M. 2013. TLC-bioautographyguided isolation, HPTLC and GC-MS-assisted analysis of bioactives of Piper betle leaf extract obtained from various extraction techniques: in vitro evaluation of phenolic content, antioxidant and antimicrobial activities. Food Analytical Methods, 6(3): 715-726.

Aziz, Z. \& Tey, N.P. 2009. Herbal medicines: Prevalence and predictors of use among Malaysian adults. Complementary Therapies in Medicine, 17(1): 44-50.

Bauer, A.W., Kirby, W.M., Sherris, J.C. \& Turck, M. 1966. Antibiotic susceptibility testing by a standardized single disk method. American Journal of Clinical Pathology, 45(4): 493-496.

Bodeker, G., Salleh, H. \& Shekar, S.C. 2009. Health and Beauty from the Rainforest: Malaysian Traditions of Ramuan. Didier Millet, Kuala Lumpur. 252 pp.

Clinical Laboratory Standards Institute. 2003. Reference method for dilution antimicrobial susceptibility tests for bacteria that grow aerobically (Approved standard M7-A6). Wayne, PA, USA.
Clinical Laboratory Standards Institute. 2006. Methods for antimicrobial disk susceptibility testing of bacteria isolated from aquatic animals (Approved guideline M2-A9). Wayne, PA, USA.

Chiao-Wei, C., Siew-Ling, H. \& Ching-Lee, W. 2011. Antibacterial activity of Sargassum polycystum C. Agardh and Padina australis Hauck (Phaeophyceae). African Journal of Biotechnology, 10(64): 14125-14131.

Cowan, M.M. 1999. Plant products as antimicrobial agents. Clinical Microbiology Reviews, 12(4): 564-582.

Davies, J. \& Davies, D. 2010. Origins and evolution of antibiotic resistance. Microbiology and Molecular Biology Reviews, 74(3): 417-433.

Food and Agriculture Organization of the United Nations. 2005. Responsible use of antibiotics in aquaculture (Fisheries Technical Paper No. 469). Rome, Italy.

Gupta, P.D. \& Birdi, T.J. 2017. Development of botanicals to combat antibiotic resistance. Journal of Ayurveda and Integrative Medicine, 8: $266-275$.

Hassan, W.E. 2006. Healing herbs of Malaysia. Federal and Development Agency, Kuala Lumpur, Malaysia. pp. 42-45.

Joshi, B., Sah, G.P., Basnet, B.B., Bhatt, M.R., Sharma, D., Subedi, K., Pandey, J. \& Malla, R. 2011. Phytochemical extraction and antimicrobial properties of different medicinal plants: Ocimum sanctum (Tulsi), Eugenia caryophyllata (Clove), Achyranthes bidentata (Datiwan) and Azadirachta indica (Neem). Journal of Microbiology and Antimicrobials, 3(1): 1-7.

Karaman, I., Şahin, F., Güllüce, M., Öçütçü, H., Şengül, M. \& Adigüzel, A. 2003. Antimicrobial activity of aqueous and methanol extracts of Juniperus oxycedrus L. Journal of Ethnopharmacology, 85(2): 231-235.

Kumar, V. \& Roy, S. 2017. Aquaculture drugs: sources, active ingredients, pharmaceutic preparations and methods of administration. Journal of Aquaculture Research and Development, 8(9): 1-13.

Latiff, A. 2007. Forestry, forest resources and forest biodiversity in Peninsular Malaysia, in: Proceedings of the National Conference on the Management and Conservation of Forest Biodiversity in Malaysia. Forestry Department Peninsular Malaysia, Kuala Lumpur, Malaysia, pp. 167-184.

Maheswaran, M.L., Padmavathy, S. \& Gunalan, B. 2013. Screening and characterization of marine seaweeds and its antimicrobial potential against fish pathogens. International Journal of Fisheries and Aquatic Studies, 1(1): 1-13. 
Mehmood, N., Zubair, M., Rizwan, K., Rasool, N., Shahid, M. \& Ahmad, V.U. 2012. Antioxidant, antimicrobial and phytochemical analysis of Cichoriumintybus seeds extract and various organic fractions. Iranian Journal of Pharmaceutical Research, 11(4): 1145-1151.

Mothana, R.A.A. \& Lindequist, U. 2005. Antimicrobial activity of some medicinal plants of the Island Soqotra. Journal of Ethnopharmacology, 96(1): 177-181.

Murray, A.G. 2009. Using simple models to review the application and implications of different approaches used to simulate transmission of pathogens among aquatic animals. Preventive Veterinary Medicine, 88(3): 167-177.

Najiah, M., Nadirah, M., Arief, Z., Zahrol, S., Tee, L.W., Ranzi, A.D., Amar, A.S., Laith, A.A., Mariam, M., Suzana, S. \& Aida, R.J. 2011. Antibacterial activity of Malaysian edible herbs extracts on fish pathogenic bacteria. Research Journal of Medical Plant, 5(6): 772-778.

Nalina, T. \& Rahim, Z.H.A. 2007. The crude aqueous extract of Piper betle L. and its antibacterial effect towards Streptococcus mutans. American Journal and Biotechnology and Biochemistry, 3(1): 10-15.

Nasir, B., Fatima, H., Ahmed, M. \& Haq, I.U. 2015. Recent trends and methods in antimicrobial drug discovery from plant sources. Austin Journal of Microbiology, 1(1): 1-12.

Naz, R. \& Bano, A. 2013. Phytochemical screening, antioxidants and antimicrobial potential of Lantana camara in different solvents. Asian Pacific Journal of Tropical Disease, 3(6): 480486.

Parekh, J., Jadeja, D. \& Chanda, S. 2005. Efficacy of aqueous and methanol extracts of some medicinal plants for potential antibacterial activity. Methods, 29(4): 203-210.

Perez, C., Paul, M. \& Bazerque, P. 1990. An antibiotic assay by the agar-well diffusion method. Acta Biologiae et Medicine Experimentalis, 15: 113 115.

Pradhan, D., Suri, K.A., Pradhan, D.K. \& Biswasroy, P. 2013. Golden heart of the nature: Piper betle L. Journal of Pharmacognosy and Phytochemistry, 1(6): 147-167.

Pridgeon, J.W. \& Klesius, P.H. 2012. Major bacterial diseases in aquaculture and their vaccine development. Animal Science Reviews, 7: 1-16.

Raman, R.P. 2017. Applicability, feasibility and efficacy of phytotherapy in aquatic animal health management. American Journal of Plant Sciences, 8: 257-287.
Rani, P. \& Khullar, N. 2004. Antimicrobial evaluation of some medicinal plants for their anti enteric potential against multi drug resistant Salmonella typhi. Phytotherapy Research, 18(8): 670-673.

Rasdi, N.H.M., Samah, O.A., Sule, A. \& Ahmed, Q.U. 2010. Antimicrobial studies of Cosmos caudatus kunth. (compositae). Journal of Medicinal Plants Research, 4(8): 669-673.

Romero, J., Feijoó, C.G. \& Navarrete, P. 2012. Antibiotics in aquaculture-use, abuse and alternatives. In: Health and Environment in Aquaculture. E.D. Carvalho, G.S. David \& R.J. Silva (Eds.). InTech, Crotia. pp.159-170.

Samir, F., Amal, D., Hafedh, H., Kais, M., Néji, G. \& Adel., K. 2017. Solvent extraction effects on phytochemical constituents profiles, antioxidant and antimicrobial activities and functional group analysis of Ecballium elaterium seeds and peels fruits. Food Science and Technology, 37(3): 483492.

Sasikumar, B. 2005. Genetic resources of Curcuma: diversity, characterization and utilization. Plant Genetic Resources: Characterization and Utilization, 3(2): 230-251.

Shaikh, T., Rub, R.A. \& Sasikumar, S. 2017. Antimicrobial screening of Cichorium intybus seed extracts. Arabian Journal of Chemistry, 9(Sup1): 1569-1573.

Subramanian, N., Jothimanivannan, C. \& Moorthy, K. 2012. Antimicrobial activity and preliminary phytochemical screening of Justicia Gendarussa (Burm.f.) against human pathogens. Asian Journal of Pharmaceutical and Clinical Research, 5(3): 229-233.

Sudheesh, P.S., Al-Ghabshi, A., Al-Mazrooei, N. \& Al-Habsi, S. 2012. Comparative pathogenomics of bacteria causing infectious diseases in fish. International Journal of Evolutionary Biology, 2012: 457264.

Sulaiman, S.A. 2019. Molecular characterization of Streptococcus agalactiae virulence gene isolated from Malaysian Hybrid Tilapia (Oreohromis spp.) (Master). Islamic International University, Malaysia.

Syahidah, A., Saad, C.R., Hassan, M.D., Rukayadi, Y., Norazian, M.H. \& Kamarudin, M.S. 2017. Phytochemical analysis, identification and quantification of antibacterial active compounds in betel leaves, Piper betle methanolic extract. Pakistan Journal of Biological Sciences, 20(2): 70-81.

Thabile, P.N. 2008. Antimicrobial Properties of Selected Asian Herbs (Master). University of Florida, USA. 
Thakare, M.N. 2004. Pharmacological Screening of Some Medicinal Plants as Antimicrobial and Feed Additives (Ph.D). Virginia Polytechnic Institute and State University, Blacksburg, Virginia, USA. Yob, N.J., Jofrry, S.M., Affandi, M.M.R., Teh, L.K., Salleh, M.Z. \& Zakaria, Z.A. 2011. Zingiber zerumbet (L.) Smith: a review of its ethnomedicinal, chemical, and pharmacological uses. Evidence-Based Complementary and Alternative Medicine, 2011: 543-216.
Zainin, N.S., Lau, K.Y., Zakaria, M., Son, R., Abdull, R. \& Rukayadi, Y. 2013. Antibacterial activity of Boesenbergia rotunda (L.) Mansf. A. extract against Escherichia coli. International Food Research Journal, 20(6): 3319-3323.

Zubair, M., Rizwan, K., Rashid, U., Saeed, R., Saeed, A.A., Rasool, N. \& Riaz, M. 2017. GC/MS profiling, in vitro antioxidant, antimicrobial and haemolytic activities of Smilax macrophylla leaves. Arabian Journal of Chemistry, 10(Sup1): 1460-1468. 